\title{
Middle Eocene Planktonic Foraminifera Inordinatosphaera aff. indica from Jabal Hafit, Al Ain area, United Arab Emirates
}

\author{
Haidar Salim Anan \\ Gaza, P. O. Box 1126, Gaza Strip, Palestine \\ E-mail: profanan@gmail.com
}

\begin{abstract}
The Middle Eocene (Bartonian) planktic foraminiferal species Inordinatosphaera aff. indica Mohan and Soodan is recorded for the first time from the Middle Eocene Orbulinoides beckmanni Zone (E12) of Jabal Hafit, Al Ain area, United Arab Emirates (UAE), Northern Oman Mountains (NOM). Thirteen commonly occurring planktic foraminiferal species associate the new one in the biozone are also recorded. The record of Inordinatosphaera aff. indica in the UAE suggests that Arabia had marine link with India during Paleogene.
\end{abstract}

Keywords: Inordinatosphaera aff. indica, Middle Eocene, Jabal Hafit, United Arab Emirates, Northern Oman Mountains

\section{INTRODUCTION}

The current work records Middle Eocene (Bartonian) planktic foraminiferal species Inordinatosphaera indica Mohan and Soodan (1967) from Jabal Hafit, Al Ain area, UAE (Lat. $24^{\circ} 06^{\prime}$ and $24^{\circ} 09^{\prime} \mathrm{N}$, Long. $55^{\circ} 46^{\prime}$ and $55^{\circ} 49^{\prime} \mathrm{E}$ ). The Maastrichtian-Paleogene rocks of the United Arab Emirates (UAE) crop out as a discontinuous mountain belt (jabals) and hills (qarns) around the western front of the North Oman Mountains (NOM). Jabal Hafit is one of these mountains, and it is a NNW-SSE asymmetrical double plunging anticline. The study area is located at the eastern limb of J. Hafit (Fig. 1). The Inordinatosphaera aff. indica Mohan and Soodan is recorded and illustrated for the first time (Fig. 3b) from the Orbulinoides beckmanni Zone (P13 of Blow, 1969 = E12 of Berggren and Pearson, 2005) of Jabal Hafit, UAE. An assemblage of thirteen Bartonian planktic foraminiferal species is also recorded from the zone. These are: Orbulinoides beckmanni (Saito), Turborotalia cerroazulensis (Cole), $T$. pomeroli (Toumarkine and Bolli), Acarinina bullbrooki (Bolli), Morozovella lehneri (Cushman and Jarvis), Truncorotaloides rohri Brönnimann and Bermúdez, T. topilensis (Cushman), Pseudohastigerina micra (Cole), Subbotina eocaena (Gümbel), S. linaperta (Finlay), S. senni (Beckmann), Globigerinatheka subconglobata (Shutskaya) and Hantkenina alabamensis Cushman.

\section{GEOLOGICAL SETTING}

The Maastrichtian-Oligocene sediments crop out around the western part of the UAE, NOM. Anan (2005) noted that the eastern limb of J. Hafit anticline exposes Middle-Upper Eocene succession along the Al Ain-Mazyad asphalted road. This succession is equivalent to 
the mappable rock unit, coded Tle4 by Hunting Ltd. (1979, where T= Tertiary, I= lower, $\mathrm{e}=$ Eocene), or Ain Al Faydah Member (formal lithostratigraphic scheme of Hamdan and Bahr, 1992) of the Dammam Formation (Krumbein, 1942).

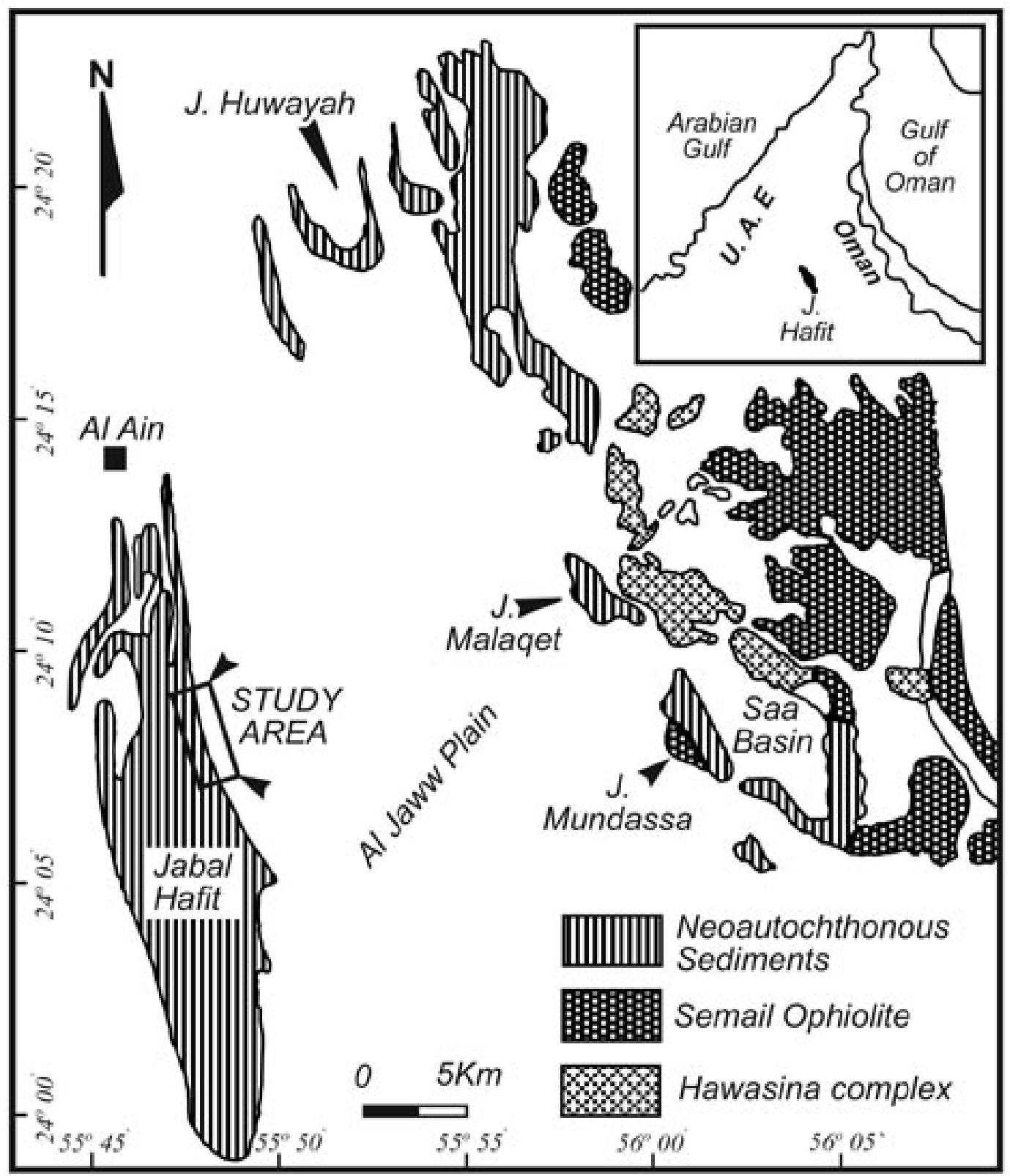

Fig. 1: Location map of the study area of Jabal Hafit, United Arab Emirates (UAE).

\section{STRATIGRAPHY OF THE STUDY AREA}

The eastern limb of J. Hafit anticline, east of Al Ain-Mazyad asphalted road, consists mainly of alternated marl, nummulitic marly limestone and hard limestone beds often with gypsiferous shale beds. One sample of gypsiferous shales (bed no. 4, about $15 \mathrm{~m}$ thick, Fig. 2) belongs to the late Middle Eocene Orbulinoides beckmanni Zone (about 40.5-40 Ma). This bed belongs to the upper part of Ain Al Faydah Member and is located about $50 \mathrm{~m}$ below the diagnostic intraformational conglomeratic bed (no. 13, Fig. 2), which separates Ain Al Faydah Member (Tle4) from Mazyad Member (Tle5) of the Dammam Formation. 


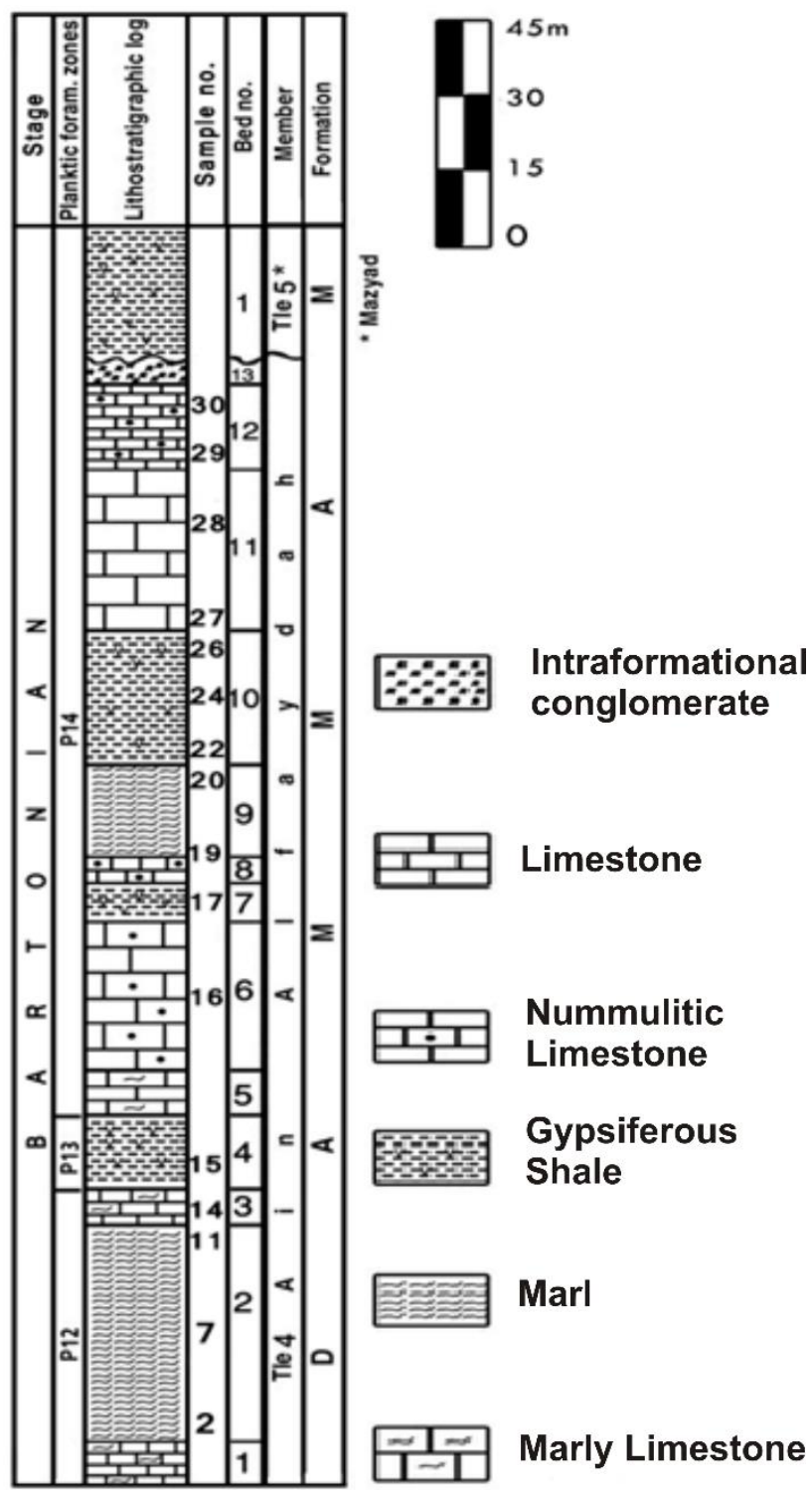

Fig. 2: Simplified stratigraphic section of the Middle Eocene, eastern limb of Jabal Hafit, UAE, Tle4= Ain Al Faydah Member, and Tle5=Mazyad Member of the Dammam Formation.

\section{SYSTEMATIC PALEONTOLOGY}

The classification of Loeblich and Tappan (1988) has been used in this study.

Order Foraminiferida Eichwald, 1830

Suborder Globigerinina Delage and Hérouard, 1896

Superfamily Globigerinacea Carpenter, Parker and Jones, 1862

Family Globigerinidae Carpenter, Parker and Jones, 1862

Subfamily Proticulasphaerinae Banner, 1982

Genus Inordinatosphaera Mohan and Soodan, 1967

Type species: Inordinatosphaera indica Mohan and Soodan, 1967

Inordinatosphaera aff. indica Mohan and Soodan, 1967

Fig.3b 
Affinity: Inordinatosphaera indica Mohan and Soodan, 1967, p. 24, fig. 1. 1-7; 1970, p. 42, pl. 2, fig. 10; Loeblich and Tappan, 1988, p. 492, pl. 539, figs. 17-23.

Description: This Lutetian taxa was recorded from India by Mohan and Soodan $(1967,1970)$ and documented in Loeblich and Tappan (1988, p. 492). It has subglobular test, early ovoid chambers in a trochospiral coil, later chambers strongly enveloping, wall calcareous hyaline with poor pits, aperture interiomarginal and umbilical in early stage, later with multiple sutural supplementary apertures covered by elongate meandriform bullae with infralaminal accessory apertures.

Material and method: Only one specimen has been recorded and this view (Fig.3b) does not match very well with the illustration provided by Mohan and Soodan (Fig.3a). Therefore, Inordinatosphaera aff. indica Mohan and Soodan is recorded tentatively and illustrated for the first time in this study from the Bartonian Orbulinoides beckmanni Zone from sample 15 (P13 of Blow, 1969 = E12 of Berggren and Pearson, 2005) of Jabal Hafit, UAE with an assemblage of thirteen Bartonian planktic foraminiferal species from this biozone.

Frequency of occurrence of the studied forms: The I. indica is rare in the study section than the other recorded planktic species with a good preservation as well as the benthic assemblage.

Repository: Geology Department, UAE University, Anan collection.

Remarks: Mohan and Soodan (1967) noted that their Middle Eocene (Lutetian) genus Inordinatosphaera differs from the Miocene genus Globigerinatella Cushman and Stainforth (1945) and the Middle Miocene-Holocene genus Orbulina d'Orbigny (1839) in having different arrangement of bullae and lacks the areal apertures, but having profuse development of bullae with infralaminal accessory apertures. I. Inordinatosphaera aff. indica is recorded for the first time from outside India.

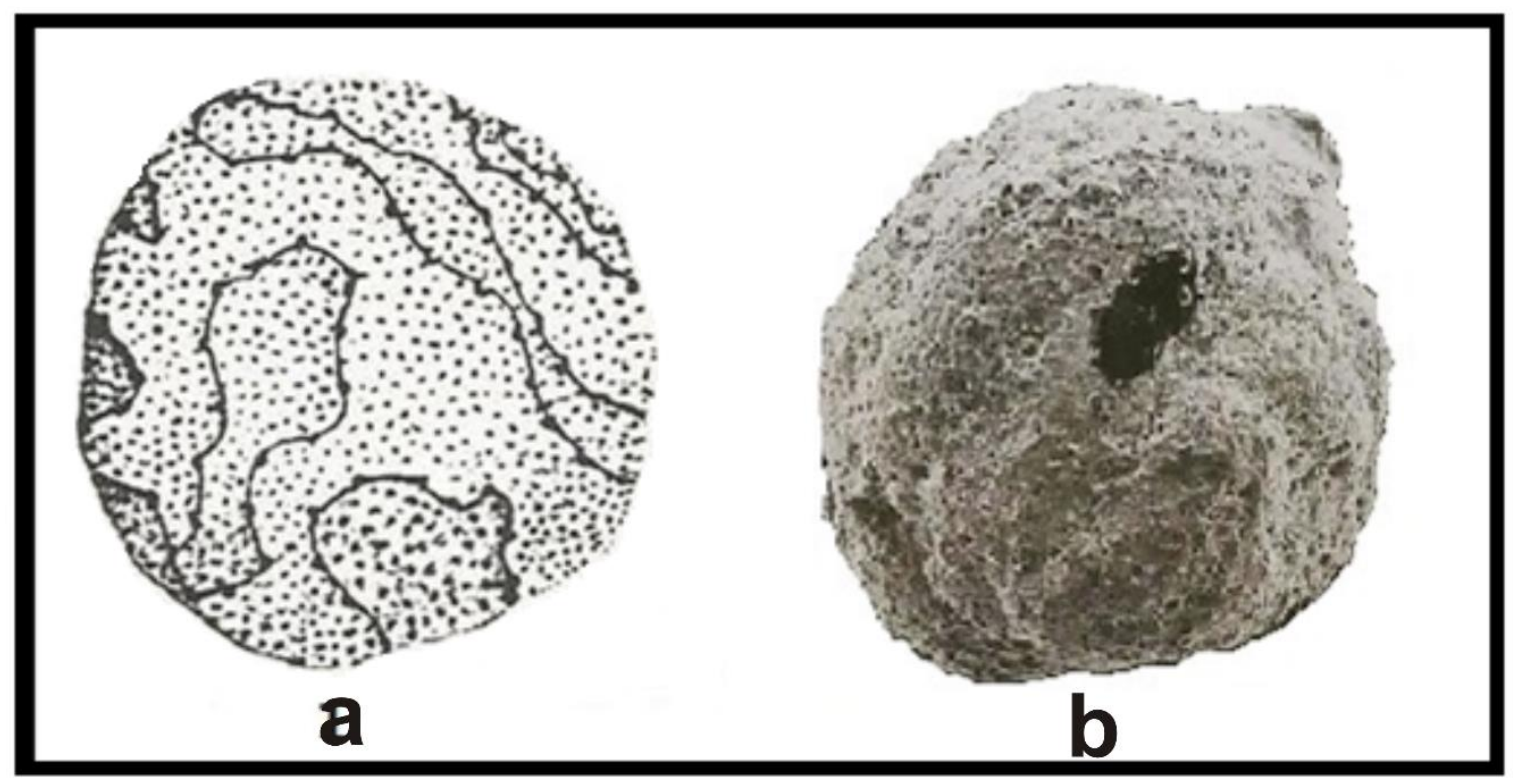

Fig. 3: a. Inordinatosphaera indica Mohan and Soodan x 60 (after Mohan and Soodan, 1970), Kutch area, India. b: Inordinatosphaera aff. indica Mohan and Soodan x 60, J. Hafit, UAE (this study). 
Discussion: The Bartonian UAE specimen of Inordinatosphaera aff. indica seems to have more similar surfacial shape with the Indian figured specimen, which is characterized by its spherical-subspherical test and irregular elongate meandriform bullae.

\section{PALEOGEOGRAPHY}

The Paleogene paleogeographic maps (partly or regionally), used by many authors, i.e. Berggren (1978), Moore et al. (1978), Adams et al. (1983) show that the Tethys had been connected with the Indo-Pacific Ocean in the east and with the Atlantic Ocean to the west. Anan (1995) concluded that the Tethyan Realm during the Middle-Late Eocene extends to the southeast and connected with the Indo-Pacific Realm via seaway. Haynes and Nwabufo-Ene (1998) suggested wider Tethyan connections, as far as the Carpathian and Pakistan. Anan (2015) recorded the Acarinina berwaliana Mohan and Soodan from the $H$. nuttalli Zone (P10) of the Kutch area (India) in the planktic assemblage from also the base of Middle Eocene (P10) of J. Hafit, UAE. The existence of Lutetian $A$. berwaliana and the Bartonian Inordinatosphaera indica (this study) strongly concluded that the Tethyan Realm during the Middle Eocene extends from Arabia to the southeast and connected with the Indo-Pacific Realm.

\section{PALEOCLIMATOLOGY}

Frerichs (1971) noted that the presence of keels, accessory apertures, and tubular spines of planktic foraminiferal species suggests a tropical sea. Anan (1994) noted that during Middle-Late Eocene time, the UAE and surrounding area had been located in the tropical and warm-temperate region. Accordingly, the Middle Eocene horizon at J. Hafit area seemed to have been located in the tropical and warm-temperate region, and this inference is based on many faunal environmental elements: presence of keel (Morozovella lehneri), accessory apertures (Truncorotaloides rohri, $T$. topilensis, Globigerinatheka subconglobata, Orbulinoides beckmanni, Inordinatosphaera indica), tubular spines (Hantkenina alabamensis) and rich Nummulitids in some horizons. This interpretation is in accordance with the environmental elements of the Middle-Late Eocene stratigraphic horizon in the UAE and surrounding area, as India.

\section{EUSTATIC SEA LEVEL}

Anan $(2005,2014)$ suggested that the unconformity at the boundary between the Ain Al Faydah and Mazyad Members in the eastern limb of J. Hafit (Fig. 2) at Al Ain Mazyad road is associated with the major sea-level lowering (about $41 \mathrm{Ma}$ ), within Truncorotaloides rohri Zone (P14). The global marked fall in the eustatic sea level (after Vail et al., 1977, Haq et al., 1987 and PHe of Keller et al., 1987) took place at the end of the Middle Eocene ( $40 \mathrm{Ma}$ ) and in Jabal Hafit as well.

Acknowledgement: The author would like to express his thanks to Prof. Hanspeter Luterbacher, Tübingen University, Germany for kind help in photography of the study species. Thanks also to Dr. S. K. Mukhopadhyay, Geological Survey of India thorough scrutiny, helpful criticism and valuable comments.

\section{REFERENCES}

Adams, C.G., Gentry, A.W. and Whybrow. P.J. (1983) Dating the terminal Tethys event. Utrecht Micropaleontological Bulletin, v. 30, pp. 273-298. 
Anan, H.S. (1994) Contribution to the stratigraphy and paleobiogeography of some diagnostic Upper Cretaceous and Paleogene Foraminifera. Neues Jahrbuch für Geologie und Paläontologie, v. 5, pp. 257-266.

Anan, H.S. (1995) Late Eocene biostratigraphy of Jabals Malaqet and Mundassa of Al Ain region, United Arab Emirates. Revue de Micropaléontologie, v. 38 (1), pp. 3-14.

Anan, H.S. (2005) Agglutinated Middle-Upper Eocene foraminifera in Jabal Hafit, Al Ain area, United Arab Emirates. Revue de Paléobiologie, v. 24 (1), pp. 17-27.

Anan, H.S. (2014) Significant episodes of tectonic activities in the Paleogene of Al Ain area, United Arab Emirates. International Journal of Chemical and Natural Science, 2 (6): 180-188.

Anan, H. S. (2015) Planktic foraminifera around the Early/Middle Eocene boundary in the United Arab Emirates and other Tethyan localities. Revue de Paléobiologie, v. 34 (1), pp. 11-25.

Berggren, W.A. (1978) Recent advanced in Cenozoic planktonic foraminiferal biostratigraphy, biochronology, and biogeography: Atlantic Ocean. Micropaleontology, v. 24 (4), pp. 337-370.

Berggren, W.A. and Pearson P.N. (2005) A revised tropical to subtropical Paleogene planktonic foraminiferal zonation. Journal of Foraminiferal Research, v. 35. 4, pp. 279-298.

Blow, W.H. (1969) Late Middle Eocene to Recent planktonic foraminiferal biostratigraphy. $1^{\text {st }}$ International Conference of Planktonic Microfossils (Geneva 1967), 1, pp. 199-422.

Frerichs, W.E. (1971) Evolution of planktonic foraminifera and paleotemperatues. Journal of Paleontology, v. 45 (6), pp. 963-968.

Cushman, J. A. and Stainforth, R. M. (1945) The Foraminifera of the Cipero marl formation of Trinidad, British West Indies. Cushman Laboratory for Foraminiferal Research, Special Publication, v. 14, pp. 1-74.

Hamdan, A.R. and Bahr, S.A. (1992) Lithostratigraphy of Paleogene succession of northern Jabal Hafit, Al Ain area, United Arab Emirates. Middle East Research Center, Ain Shams University, Earth Science Series, Cairo, v. 6, pp. 201-224.

Haynes, J. and Nwabufo-Ene, K. (1998) Foraminifera from the Paleocene phosphate beds, Sokoto, Nigeria. Revue Española de Micropaleontologia, v. 30 (2), pp. 51-76.

Haq, B.U., Hardenbol, J. and Vial, P.R. (1987) Chronology of fluctuating sea level since the Triassic. Science, New York, v. 235, pp. 1156-1167.

Hunting Geology and Geophysics Limited (1979) Report on a Mineral Survey of the United Arab Emirates, Al Ain area. Ministry of Petroleum and Mineral Resources, Abu Dhabi, v. 9, pp. 1-29.

Keller, G., Herbert, T., Dorsey, R., D'Hondt, S., Johnsson, M. and Chi, W.R. (1987) Global distribution of late Paleogene hiatuses. Geology, v. 15, pp. 199-203.

Krumbein, W.C. (1942) Criteria for subsurface recognition of unconformities. American Association of Petroleum Geological Bulletin, v. 26, pp. 36-62.

Loeblich, A.R. and Tappan. H. (1988) Foraminiferal genera and their classification. Van Nostrand Reinhold (VNR), New York, Part 1, 970 p., Part 2, 847 p.

Moore, Jr. T.C., Van Andel, Tj.H., Sancetta, C. and Pisias. N. (1978) Cenozoic hiatuses in pelagic sediments. Micropaleontology, v. 24 (2), pp. 113-138. 
Middle Eocene Planktonic Foraminifera Inordinatosphaera aff. indica from Jabal Hafit, Al Ain area, United Arab Emirates: Anan

Mohan, M. and Soodan, K.S. (1967) Inordinatosphaera- a new genus of Globigerinidae. J. Geological Society of India, v. 4 (1), pp. 22-25.

Mohan, M. and Soodan. K.S. (1970) Middle Eocene planktonic foraminiferal zonation of Kutch, India. Micropaleontology, v. 16 (1), pp. 37-46.

Orbigny, A. d'. (1839) Foraminifères. In: Ramon de la Sagra, Histoire physique, politique et naturelle de l'ile de Cuba). Paris, Arthus Bertrand, 224p.

(Received: 24.02.2017; Accepted:28.07.2017) 